\title{
Understanding Level of Technology Pedagogy and Content Knowledge (TPACK) Students of Architectural Engineering Education Study Program
}

\author{
Rr. Tjahyani Busono, Riskha Mardiana, Kunthi Herma Dwidayati \\ Indonesia University of Education , Bandung, Indonesia
}

Corresponding author: tiahyanibusono@upi.edu ; riskhamardiana@upi.edi ; dwidayati@upi.edu

$\begin{array}{cccc} & & \text { Article History: } \\ \text { Received: } 14 \text { January } & \text { Revised: } 28 \text { March } & \text { Accepted: } 14 \text { April } & \text { Available online: } 26 \text { April } \\ 2021 & 2021 & 2021 & 2021\end{array}$

\begin{abstract}
The Law of the Republic of Indonesia Number 14 of 2005 concerning Teachers and Lecturers states that a teacher must have four competencies, namely pedagogical competence, personality, social and professional competences. A teacher is expected to pay attention to the material, strategy, technology or surrounding culture in helping to realize active, creative, fun and meaningful learning. One of the uses of ICT in education is needed as an effort to improve the efficiency and effectiveness of the learning process. However, there are many obstacles faced in its application, including a lack of teacher understanding of technology. Technological Pedagogical and Content Knowledge (TPACK) is a framework that describes the knowledge needed by teachers to integrate technology in designing, implementing and evaluating learning. This study aims to determine the level of understanding of the Technological Pedagogical and Content Knowledge of students of the Architectural Engineering Education Study Program who are also prospective teachers. The research method used is descriptive evaluative with a quantitative approach. Retrieval of data using a survey method of 35 respondents from students of the Architectural Engineering Education Study Program who have been and are currently participating in the Field Experience Program at Vocational High Schools in various regions in West Java. The instrument used was a closed questionnaire where each statement was based on each TPACK component. The results showed that the average level of understanding of Architectural Engineering students towards TPACK was in the good category. The highest value is in the aspect of Technology Knowledge (TK), which is knowledge about technology with a very high category.
\end{abstract}

Keywords: TPACK; SMK; technology

\section{Introduction}

The 2013 Vocational High School (SMK) curriculum requires a learning process to be held interactively, inspiring, fun, challenging, motivating students to actively participate, and providing sufficient space for initiative, creativity, and independence according to their talents, interests and physical development. as well as psychological students. For this reason, each education unit carries out lesson planning, implementation of the learning process and assessment of the learning process to increase the efficiency and effectiveness of the achievement of graduate competencies.

The use of computers in education is the first step towards creating a technological society. Educational institutions need to make optimal use of the potential of information and communication technology (ICT). With the rapid development of telecommunication, multimedia, and information technology, listening to lectures, taking notes on paper is of course outdated. The incorporation of technological aspects in learning is an effort to foster and foster interest and 
positive attitudes towards technological developments. Understanding of ICT in an integrated manner is much more important than just understanding ICT as a learning aid. The developing paradigm is technology can support inquiry learning, collaboration and repositioning in carrying out the learning process (Sutrisno, 2012). There are various models of ICT integration framework in learning, one of which is the Technology Pedagogy and Content Knowledge (TPACK) framework. The development of this framework according to Mishra and Kohler (2008) is based on three important components of knowledge that must be possessed as an educator, namely mastery of subject matter in accordance with the qualifications and competencies contained in the curriculum, pedagogy and technology.

The Law of the Republic of Indonesia Number 14 of 2005 concerning Teachers and Lecturers states that a teacher must have four competencies, namely pedagogical competence, personality, social and professional competences. Pedagogic competence is seen as the teacher's ability to manage learning. Personality competence reflects an authoritative personal ability and character as a teacher. Furthermore, social competence is seen as the teacher's ability to interact with students, guardians of students, teachers or other education personnel, as well as the surrounding community. Meanwhile, professional competence is seen as the ability to master the material, its implementation, and mastery of science, technology, art or culture. So it can be concluded that in designing learning activities a teacher is expected to pay attention to the material, strategy, technology or surrounding culture in helping to realize active, creative, fun and meaningful learning.

One of the uses of ICT in education is needed as an effort to improve the efficiency and effectiveness of the learning process. However, there are many obstacles faced in its application, including a lack of teacher understanding of technology. This study seeks to describe the teacher's understanding, in terms of the TPACK (Technological, Pedagogical and Content Knowledge) framework.

\section{Problem Formulation}

The formulation of the problem in this study is "how to describe the level of understanding of the Technological Pedagogical And Content Knowledge of students of the Architectural Engineering Education Study Program?"

\section{Research Objectives}

This study aims to determine the level of understanding of the Technological Pedagogical And Content Knowledge of students of the Architectural Engineering Education Study Program.

\section{Literature Review}

Constructivism learning theory holds that the media is used as something that allows students to actively construct knowledge. Media can be distinguished from technology (mechanical, electronic, physical form), symbolic systems (numeric characters, objects, images, sound) and the means used (radio, video, computer, books) (Munir, 2008). One of the learning media is ICT. Integrating ICT into learning aims to improve the competence of teachers in teaching and improve the quality of learning of students. One of the lessons that integrate ICT is Technology Pedagogy Content Knowledge (TPCK).

The basic concept of TPCK according to Mishra and Kohler (2008) emphasizes the relationship between subject matter, technology and pedagogy. The interaction between the three components has the strength and attractiveness to foster active learning that is focused on students. This can also be interpreted as a form of shift in learning that was originally teachercentered shifting to students. The relationship between the constituent components of the TPCK is shown in Figure 1. 


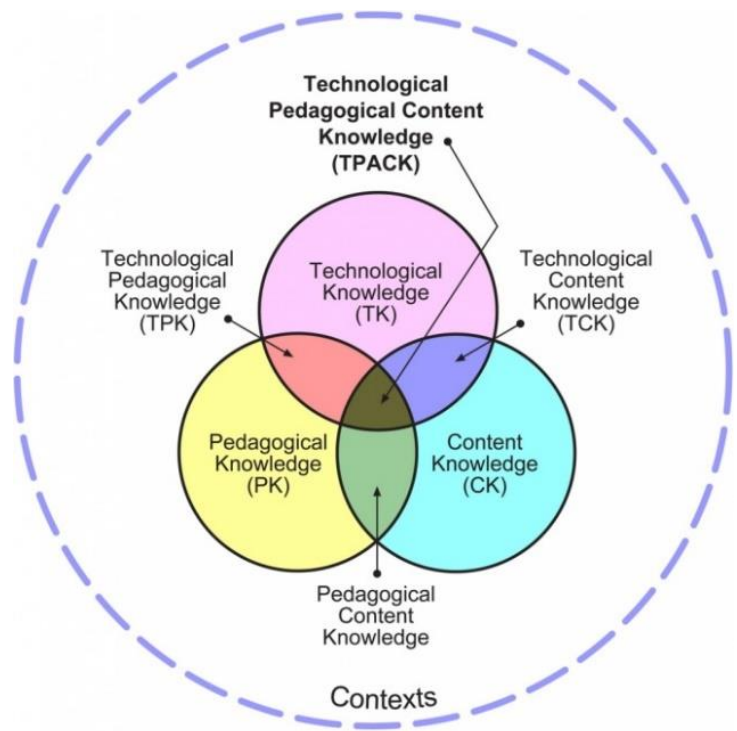

Figure 1. TPACK

Source: www.tpck.org, (2012)

Sutrisno (2012) explains that the TPCK concept consists of: (1) Content Knowledge (CK), namely knowledge of the material to be studied; (2) Pedagogy Knowledge (PK) describes in depth the theory and practice of teaching and learning, namely objectives, processes, learning methods and strategies, and assessment; (3) Technology Knowledge (TK) is the basics of technology that can be used to support learning, such as the use of software, animation programs, virtual laboratories.

TPCK summarizes a series in which the ability to master technology in an integrated manner that cannot be separated from one another from its constituent components, namely material (C), pedagogy $(\mathrm{P})$ and technology (T). TPCK requires the occurrence of multiple interactions and a combination of components, namely unique and synergistic subject matter, pedagogy and technology based on Information and Communication Technology (Mishra and Kohler, 2006).

The application of the TPCK framework is also in line with the knowledge acquisition theory. Rusman (2012) suggests that the acquisition of knowledge, changes in attitudes and skills can occur because of the interaction between new experiences and experiences that have been experienced before. According to Bruner (Rusman, 2012), there are three main levels of learning mode, namely direct experience, image experience and abstract experience.

The development of ICT allows the use of the functions of various learning media using a single tool called multimedia, which is able to convey information and learning material in the form of text, images, sound, animation, film, and even interactions. Computers are one of the multimedia tools, because computers are capable of presenting information and learning materials in all forms, even with real-world computers that take a long time or are very expensive and carry the risk of being simulated by a computer (for example a chemical reaction process, the impact of a nuclear explosion, travel solar system, etc.). Through multimedia, abstract concepts can be presented more clearly in the learning process to make it easier for students to understand them (Munir, 2008).

\section{Research Method}

The research was conducted using a descriptive evaluative method. Descriptive method is used in this research to collect data about existing conditions. The evaluative method was used to evaluate the level of understanding of the Technological Pedagogical and Content Knowledge students of the Architectural Engineering Education Study Program. The data needed in this study is quantitative data, with a single variable data type, namely the level of understanding of Technological Pedagogical and Content Knowledge of students of the Architectural Engineering Education Study Program. The instrument used in this study was a closed questionnaire containing statements that must be filled in by the teacher about their agreement or disagreement with the statements given in the questionnaire (Likert scale). The statements made are adjusted to the TPACK indicator (adapted by Suryawati et al., 2014; Tian et al. 2012; Chai, Koh, Tsai, \& Tan, 
2011; Schmidt et al, 2009) which includes Technological Knowledge (TK), Content Knowledge ( CK), Pedagogical Knowledge (PK), Technological Content Knowledge (TCK) Technological Content Knowledge (TCK) Pedagogical Content Knowledge (PCK), Technological Pedagogical Knowledge (TPK), and Technological Pedagogical Content Knowledge (TPCK). The TPACK questionnaire developed consists of 30 statements that must be filled in by respondents.

\section{Results and Discussion}

\subsection{Description of Data}

This research was conducted to evaluate the students' ability (self-assessment) of prospective Architectural Engineering Education teachers in understanding Technological Pedagogical And Content Knowledge (TPACK).

The level of understanding of the Technological Pedagogical and Content Knowledge of students of the Architectural Engineering Education Study Program was netted by using a questionnaire with student respondents who had participated in the Field Experience Program at various Building Vocational Schools in West Java. Technological Pedagogical And Content Knowledge (TPACK). Developed from the theory expressed by Schmidt, Thompson, and Koehler, which consists of 7 aspects, namely: Technology Knowledge (TK), Content Knowledge (CK), Pedagogical Knowledge (PK), Pedagogical Content Knowledge (PCK), Technological Pedagogical Knowledge (TPK), Technological Pedagogical Content Knowledge (TPACK) was developed into 30 closed question items using a Likert scale.

Classification of scores on the TPCK questionnaire data for Architectural Engineering Education students who have implemented PPL, can be seen in table 1. In table 1 below shows the TPACK ability of Architectural Engineering Education students, as prospective teachers are in the good category with an average score of 3.5. The highest value is in the aspect of Technology Knowledge (TK), which is knowledge about technology, which is very well understood, that students of class 2016 as respondents born in 1998-2010 are generation z.

Table 1 Recapitulation of Questionnaire Analysis Results on Each Aspect of TPACK

\begin{tabular}{|l|c|c|}
\hline & Rata-rata & Kriteria \\
\hline $\begin{array}{l}\text { Technology Knowledge } \\
\text { (TK) }\end{array}$ & 3.8 & Very Good \\
\hline $\begin{array}{l}\text { Content Knowledge } \\
\text { (CK), }\end{array}$ & 3.5 & Good \\
\hline $\begin{array}{l}\text { Pedagogical Knowledge } \\
\text { (PK), }\end{array}$ & 3.5 & Fair Enough \\
\hline $\begin{array}{l}\text { Pedagogical Content } \\
\text { Knowledge (PCK), }\end{array}$ & 3.31 & Good \\
\hline $\begin{array}{l}\text { Technological } \\
\text { Pedagogical Knowledge } \\
\text { (TPK) }\end{array}$ & 3.5 & Good \\
\hline $\begin{array}{l}\text { Technological Content } \\
\text { Knowledge (TCK), }\end{array}$ & 3.5 & Fair Enough \\
\hline $\begin{array}{l}\text { Technological } \\
\text { Pedagogical Content } \\
\text { Knowledge (TPACK) }\end{array}$ & 3.4 & Good \\
\hline Rata-rata & 3.5 & \\
\hline
\end{tabular}

Generation $z$ is a generation that is exposed to digital technology that has been established and reached its peak, massively since they were born. who are proficient and like information technology from various computer applications (Hinduan. et al, 2017). In general, their skills in information technology and computers (ICT) are very good. Learning methods or strategies that have optimized the use of information and communication technology (ICT) in lectures, strengthen students' abilities and make it part of their daily behavior. 


\section{A. Technology Knowledge (TK)}

Technology Knowledge refers to the ability of students to use digital technology such as social media, such as blogs, websites to digital technology used for learning that is integrated with the curriculum. For Architecture students, the ability and skills to draw digitally are demanded.

Based on the results of the analysis of the ability of Technology Knowledge (TK) students are in the very good category with an average score of 3.8. This shows that the knowledge and skills of architectural education students as prospective teachers in technology are very good.

\section{B. Content Knowledge (CK)}

Content Knowledge, refers to the knowledge of subject matter that must be mastered while teaching (Kohler et al., 2014; Schmidt \& Mishra, 2009), includes theories, ideas, frameworks (Schulman, 1986). In this study, materials related to subjects in SMK Building Drawing Engineering study program.

The description in this study is whether students have sufficient knowledge in a subject, have a strategy in subject delivery, ability in subject development, and master a subject and can integrate with other sciences.

Based on the results of the analysis of their Content Knowledge (CK) abilities, students are in the good category with an average score of 3.5. This shows that knowledge of the material being taught, strategies for delivering material, developing teaching materials and integrating other sciences and the world of work are in a good category. Knowledge of the content of the material being taught must be mastered by a teacher, to avoid misconceptions in providing explanations and showing facts (Kohler \& Mishra. 2009).

\section{Pedagogical Knowledge (PK)}

Pedagogical Knowledge, refers to the ability of prospective teacher students to manage classes, guide students to learn independently, guide students to learn in groups, use interactive learning methods and teach students to monitor their own learning.

Based on the results of the analysis of the students' Pedagogical Knowledge (PK) ability, they are in the good category with an average score of 3.5. This shows that students of Architectural Engineering Education prospective teachers can implement pedagogical principles, starting from planning, implementing, and assessing learning in class during the Field Introduction Program at SMK in either category.

\section{Pedagogical Content Knowledge (PCK),}

Pedagogical Content Knowledge, according to Shulman (Shulman, 1986), emphasizes the importance of integrating teacher content knowledge with pedagogical knowledge, how to formulate subjects that can be understood by others. Shulman defines PCK beyond content or subject matter knowledge to include knowledge of how to teach certain content. An overview of the ability of students of Architectural Engineering Education in developing knowledge / content of subject matter as outlined in the syllabus, compiling lesson plans, evaluating student learning outcomes and implementing learning with various methods.

Based on the analysis of the Pedagogical Content Knowledge (PCK) ability, students are in the quite good category with an average score of 3.21. This shows that students of Architectural Engineering Education prospective teachers are quite good at developing knowledge / content of the subject matter as outlined in the syllabus, compiling lesson plans, evaluating student learning outcomes and teaching them in various learning strategies.

\section{E. Technological Pedagogical Knowledge (TPK)}

Technological Pedagogical Knowledge, is knowledge of how technology can facilitate pedagogical approaches, such as using asynchronous discussion. In the development of Koehler and Mishra's (2005) model, an aspect of technological knowledge has been added, which refers to knowledge of how to work with and apply technological resources. In the context of this research, how would prospective teachers and teachers use technology to teach.

An overview of the ability of Architecture Education students in using digital technology in learning activities, sorting and adjusting the digital technology that is studied appropriately for different learning, thinking critically in using digital technology in teaching and learning process or student forum discussion.

Based on the results of the analysis of the students' Technological Pedagogical Knowledge (TPK) abilities, they are in the good category with an average score of 3.5. This shows that 
students of Architectural Engineering Education prospective teachers are good at using digital technology in learning activities, sorting and adjusting digital technology that is studied appropriately for different learning, thinking critically in using digital technology in the teaching and learning process and using digital technology in discussion activities. student forum.

\section{F. Technological Content Knowledge (TCK)}

Technological Content Knowledge, this explains the teacher's understanding of how technology and content can influence and encourage one another. TCK involves understanding how subject matter can be communicated with different technologies, and considering specific learning technology tools that are best suited for a particular subject matter or classroom. Description of the ability of students of Architectural Engineering Education, as prospective teachers from the Field Experience Program.

Based on the results of the analysis of students' Technological Content Knowledge abilities, they are in the good category with an average score of 3.5. This shows the ability of Architectural Engineering Education students in using appropriate digital technology to represent subject matter, carrying out the learning process using technology such as computers, LCD projectors, plotters, 3D printers etc., making questions using software in the form of videos or learning media made by students as an effort to improve student learning outcomes or applications and evaluate the results of assignments using software or applications is good.

\section{G. Technological Pedagogical Content Knowledge (TPACK)}

Technological Pedagogical Content Knowledge, according to Angel Valanides, 2005. Mishra \& Koehler, 2009 TPACK is a framework that can integrate aspects of technological knowledge, pedagogy, and content as a whole so as to generate new thinking patterns about combining these three aspects in learning. By integrating the three aspects of technology, pedagogy, and content in learning, of course, it can provide variety in learning. In addition, according to Hewitt, PACK is considered a potential framework that can provide new directions for teachers in solving problems related to integrating ICT into teaching and learning activities in the classroom (Hewitt, 2008).

Based on the results of the analysis of the ability of the Technological Pedagogical Content Knowledge (TPACK) students are in the quite good category with an average score of 3.4. This shows that students of Architectural Engineering Education prospective teachers have a strategy in combining content, digital technology and learning approaches, are able to guide and direct students in choosing digital technology and content in the learning process, are able to teach content with a pedagogical approach through the use of digital technology, are able to provide assignments Certain subject groups using digital technology, being able to make questions on a subject using applications, and evaluating student learning outcomes in a subject using digital technology in a fairly good category.

\subsection{Level of Understanding of TPACK Students of Architectural Engineering Education}

The level of understanding / ability of the Technological Pedagogical And Content Knowledge students of the Architectural Engineering Education Study Program is obtained from the comparison of the scores obtained by students divided by ideal scores and converted to assessment guidelines according to table 2 .

Table 2 Guidelines for Conversion Assessment

\begin{tabular}{|c|c|c|}
\hline No & Categories & Amounts \\
\hline 1 & Very Good & $90,0-100,0$ \\
\hline 2 & Good & $75,1-89,9$ \\
\hline 3 & Fair Enough & $60,0-75,0$ \\
\hline 4 & Less & $0,00-59,9$ \\
\hline
\end{tabular}


Table 3 Score of TPACK Ability Level

\begin{tabular}{|c|c|c|c|}
\hline & $\begin{array}{c}\text { Jumlah } \\
\text { Responden }\end{array}$ & Prosentase & Kategori \\
\hline $90,0-100,0$ & 8 & $22.86 \%$ & Very Good \\
\hline $75,1-89,9$ & 21 & $60 \%$ & Good \\
\hline $60,0-75,0$ & 6 & $17.14 \%$ & Fair Enough \\
\hline $0,00-59,9$ & - & - & Less \\
\hline
\end{tabular}

In table 3. It can be seen that the level of ability obtained by students of Architectural Engineering Education is in the very good category as much as $22.86 \%$, the good category is $60 \%$ and the good enough category is $17.14 \%$. There is no student who is lacking in TPACK ability. If the TPACK ability score is averaged, then a score of 83 is obtained, in a good category.

\section{Conclusion}

The conclusion of this study shows that the Technological Pedagogical and Content Knowledge ability level of students of the Architectural Engineering Education Study Program as prospective teachers is in the capable or good category with a score of 83.

The highest value is in the aspect of Technology Knowledge (TK), which is knowledge about technology with a very high category, this can be understood, that students of class 2016 as respondents born in 1998-2010 are generation $z$ who grew up in the era of gadgets.

\section{Suggestions}

- The lowest score was on the Pedagogical Content Knowledge (PCK) aspect, although it was still in the good category. This of course must be the concern of the study program to make efforts to increase student knowledge and ability to formulate teaching material so that it can be better understood by students.

- In the aspect of Technological Pedagogical And Content Knowledge, it is also in the good category but gets the second lowest score. Although students' abilities in knowledge in operating computers and software are in the very good category, it is still necessary to improve the skills of professional ICT-based teachers.

\section{References}

Anonim. (2012). TPACK. www.tpack.org [diakses, 27 Juli 2012].

Chai C.S, Koh, Tsai, \& Tan (2011). Modeling primary school pre-service teachers'Technological Pedagogical Content Knowledge (TPACK). Computers \& Education, 57(2011), 11841193.

Chai, C.S., Koh, J. H.L., \& Tsai, C.C. (2013). A Review of Technological Pedagogical Content Knowledge. Educational Technology \& Society, 16 (2), 31-51.

Chai, C. S., Koh, J. H. L., \& Tsai, C.-C. (2016). 6A Review of the quantitative measures of Technological Pedagogical Content Knowledge (TPACK). In Handbook of technological pedagogical content knowledge (TPACK) for educators (hal. 97-116). Routledge.

Depdiknas .2006. Permendiknas No 22 Tahun 2006 Tentang Standar Isi. Jakarta : Depdiknas.

Hinduan, Z.r.,M.I. Agia, dan S. Kholiq.2017. Generation Z in Indonesia : Psychological Capital, Work Value, and Learning Style. Universitas Padjadjaran.

Kocoglu, Z. (2009). Exploring The Technological Pedagogical Content Knowledge of Pre-service Teachers in Language Education. Dalam Procedia Social and Science [Online], Vol. 1 (2734-2737). DOI: 10.1016/j.sbspro.2009.01.485

Marzano \& Heflebower (2012). Teaching \& Assessing 21st Century Skills. Marzano Research Laboratory; 1 edition (August 8, 2011)

Mishra dan Kohler, M (2006), Technological Pedagogical Content Knowledge: A Framework for Teacher Knowledge. Teachers College Record Volume 108, Number 6, June 2006, pp. 1017-1054 
Mishra dan Kohler, M (2008), Handbook of Technological Pedagogical Content Knowledge (TPACK) for Educators. New York: Routledge for the American Association of Colleges for Teacher Education.

Mishra, et. al. (2009). Technological Pedagogical Content Knowledge (TPACK): The Development and Validation of an Assessment Instrument for Preservice Teachers.. Journal of Research on Technology in Education 42(2), 123-149

Munir, (2008), Kurikulum Berbasis Teknologi Informasi dan Komunikasi. Bandung: Alfabeta.

Parkay, F. W., \& Stanford, B. H. (2009). Becoming a teacher (8th ed.). Boston, MA: Allyn and Bacon.

Rusman, (2012), Belajar dan Pembelajaran Berbasis Komputer: Mengembangkan Profesionalisme Guru Abad 21. Bandung: Alfabeta.

Shavelson, R., Ruiz-Primo, A., Li, M., \& Ayala,C. (2003, August). Evaluating new approaches to assessing learning (CSE Report 604). Los Angeles, CA: University of California, National Center for Research on Evaluation.

Sagala, S. (2009). Kemampuan Profesional Guru dan Tenaga Kependidikan. Bandung: Alfabeta

Schmidt, D. A., Thompson, A. D., Koehler, M. J., \& Shin, T. S. (2009). Technological Pedagogical Content Knowledge (TPACK): the development and validation of an assessment instrument for preservice teachers. Journal of Research on Technology in Education, 42(2), 123-149.

Suryawati, E., Hernandez, Y. Firdaus L.N. (2014). Analisis Keterampilan Technological Pedagogical Content Knowledge (TPCK) Guru Biologi SMA Negeri Kota Pekanbaru. Jurnal Biogenesis. 11 (1), 67-72.

Sutrisno, (2012), Kreatif Mengembangkan Aktivitas Pembelajaran Berbasis TIK. Jakarta: Referensi.

Tsai, H.C. (2015). A senior teacher's implementation of technology integration. International Education Studies, 8(6): 151-161.

Undang-Undang Republik Indonesia Nomor 14 Tahun 2005 tentang Guru dan Dosen. 